Canadian Journal of Higher Education Revue canadienne d'enseignement supérieur

Volume 46, No. 4, 2016, pages 41 - 59

\title{
The International Mobility of Chinese Students: A Cultural Perspective
}

Wei Liu

University of Alberta

\begin{abstract}
Anyone hoping to understand China and Chinese people's behaviour in the present day must examine China's long history and culture, as these often have crystallized into current behavioural patterns. This paper discusses one important push-out factor for Chinese students' outbound mobility, and an element that is ignored in many futuristic predictions of international student mobility: traditional Chinese educational culture. I conduct an in-depth analysis of three major aspects of Chinese educational culture in relation to Chinese students' international mobility: the education-first culture, the saving culture, and the extended-family culture. I argue that these three aspects will continue to drive Chinese students' outbound mobility.
\end{abstract}

\section{Résumé}

Si on veut comprendre la Chine et le comportement de son peuple aujourd'hui, il faut repenser à la longue histoire et à la culture de ce pays. En effet, le passé du peuple chinois se cristallise souvent dans ses modèles de comportement actuels. Cet article aborde un élément important de la mobilité des étudiants chinois vers des pays étrangers, élément ignoré par de nombreuses prédictions futuristes quant à la mobilité des étudiants internationaux, notamment quant à la culture éducative traditionnelle chinoise. L'auteur mène une analyse détaillée sur trois aspects significatifs de la culture éducative chinoise par rapport à la mobilité internationale des étudiants chinois : une culture qui privilégie l'éducation avant tout, une culture de l'épargne et une culture des familles élargies. Ces trois aspects de la culture éducative chinoise continueront à stimuler la mobilité des étudiants chinois vers des pays étrangers. 
China is currently the number one source country of international students around the world. From 1978 to 2013, the total number of Chinese students who went overseas to study reached over 3 million (EOL, 2014). In 2011 alone, the total number of Chinese students studying overseas was 339,700 (comprising 14\% of students studying abroad around the world), among whom 90\% were studying at their own expense (Yangtze Evening Post, 2012).

Currently, there are 95,160 Chinese students studying in Canada-about one-third of all international students in Canada (295,505) (CBIE, 2014) and 10\% of all Chinese students currently studying overseas. This makes Canada the fourth most desirable destination for Chinese students, after the USA (30\%), the UK (21\%), and Australia (13\%) (EOL, 2014).

In 2008, Chinese students contributed over USD 15 billion a year to their host countries' economies, almost half of China's total higher education spending (Zha, 2011). Canada derives CAD 8 billion annually from international student expenditures, including tuition and living expenses (Roslyn Kunin \& Associates, 2012), and in 2009, international education as an industry created over 83,000 jobs and generated more than CAD 291 million in government revenue (CBIE, 2014). As Chinese students comprise one-third of the total international student population, this means that Chinese students alone spend close to CAD 2.7 billion a year in Canada, contributing to nearly 18,000 jobs and generating CAD 97 million in government revenue.

The huge tide of Chinese students flowing overseas for higher education, particularly self-supporting undergraduate students, has been much appreciated by cash-strapped universities in the West. In Canada, tuition fee income makes up about $23 \%$ of the average university's operating budget, of which over $25 \%$ is contributed by international students, who constitute about 10\% of the university population (based on Statistics Canada, 2012). While Western universities, mostly in English-speaking countries, step up their efforts in a fierce competition for Chinese students, they all seem to have a deep sense of concern and uncertainty over the future supply of Chinese students and the sustainability of the stream of revenue generated by international tuition fees. Given the context of such concern and uncertainty, Western universities eagerly seek accurate forecasts regarding trends in international student mobility.

\section{Current Models of Prediction}

One important way to examine the pattern of international student mobility is to look at the push and pull factors (Altbach, 1998). Students are pushed to go overseas by unfavourable conditions in their home countries. They are also pulled to come out by the favourable conditions offered by the host countries.

The push factors, in the Chinese case, may include the fierce competition for admission into "brand-name" higher education institutions and the perceived poorer quality of education in third-tier and fourth-tier institutions, which may result in low chances of employment upon completion. Of course, one enabling push factor is the increase in household income that has made high international tuition fees affordable to more Chinese families. The pull factors may include the perceived better quality of English-medium education overseas, the ability to enter a particular program not available at home, the desire to gain overseas experience and international competence, and the intention to immigrate after graduation (based on Mazzarol \& Soutar, 2001). 
The pull factors seem to have stayed more or less stable over the past few decades in major destination countries, although these countries have had different policy changes, which have resulted in changes in the distribution of international students among them. What has been the focus in predictions about future international student mobility are the push factors. The most prominent push factors in the case of China are the Chinese demographic trend, the development of Chinese higher education, and the trend of China's economic growth. A good example of forecasting is the British Council and IDP Australia's report Vision 2020. Forecasting International Student Mobility: A UK Perspective (Böhm et al., 2004).

Demographic analysis typically examines the tertiary age population in China, which is an indication of the demand for higher education. The Chinese population is aging rapidly, given the national family planning policy established in the 1970s. The tertiary age population is dwindling, which is shown by the declining number of Chinese students taking national university entrance exams (Gaokao) from 2008 to 2013, with a change of trend only in 2014 (based on Sina Education, 2015). Between 2008 and 2011, the population of Gaokao takers shrank by 1.4 billion (Zha, 2011) at a yearly rate of about $2.5 \%$.

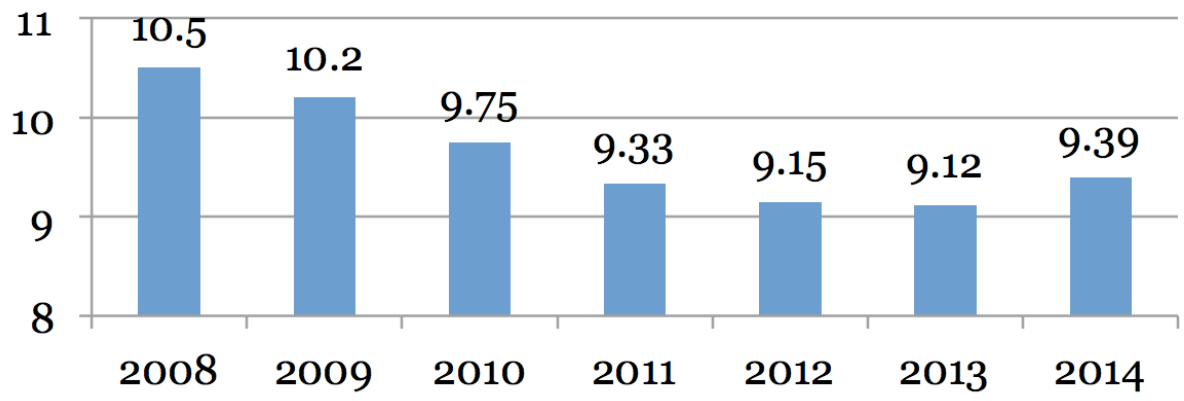

Figure 1. Declining number of "Gaokao" takers (millions)

What about the supply side? From 1999, China began its aggressive university expansion plan. China aimed to reach $15 \%$ enrolment in higher education by 2010 , an objective based on Martin Trow's (1974) definition of "mass higher education" (Bai, 2006). The goal was achieved many years earlier than planned, with Chinese higher education enrolment growing at a yearly rate of 17\% between 1998 and 2010 (Zha, 2011). In 1990, less than $4 \%$ of $18-22$-year-olds enrolled as students in higher education institutions. By 2005, the number had risen to $22 \%$, with the total number of students in higher education exceeding 23 million in 2006 (Brandenburg \& Zhu, 2007). As of 2011, an average of 78\% of the Gaokao takers had the chance to go to an institution of higher learning (Zha, 2011).

If we combine the effect of the declining rate of Gaokao entrants $(2.5 \%)$ and the increasing rate of higher education provision in China (17\%), both being negative factors for Chinese students' outward mobility, then we should have seen a yearly $19.5 \%$ decrease in Chinese students studying overseas during the past decade or so. However, what we saw was a 25\% yearly increase between 1998 and 2013. The following chart shows the increase in Chinese students studying overseas from 2008 to 2014 (based on People.cn, 2014; Wang, 2015): 


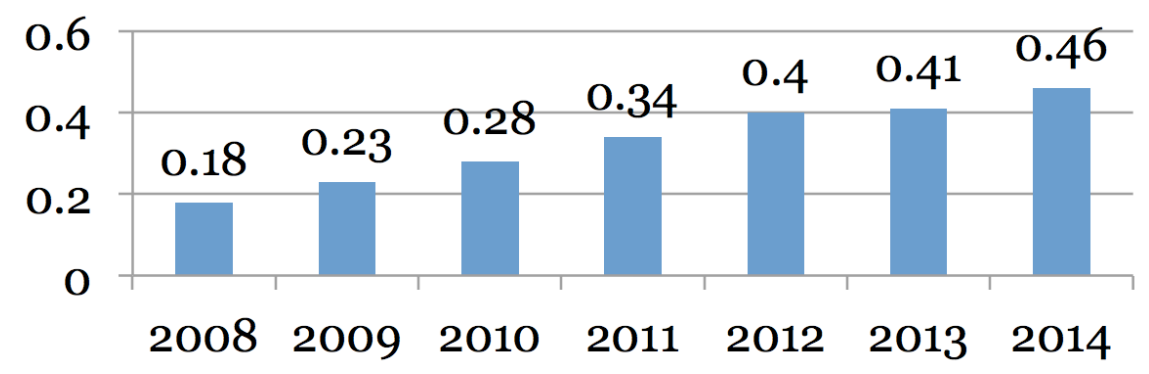

Figure 2. Increasing number of Chinese students studying overseas (millions)

The reason for the discrepancy might be economic trends in the past decade. Economic analysis typically looks at whether the Chinese economy will continue to grow and to do so rapidly, and whether the wealth will trickle down and create more high-income families. Cross-nationally, economic analysis also examines the dynamics of the exchange rate, as a stronger renminbi (RMB) will make education abroad more affordable to the Chinese. As the whole world knows, the Chinese economy has grown at a yearly rate of about $10 \%$ in the past few decades, and the value of the RMB grew gradually but steadily. But even if we factor in this $10 \%$ growth rate into the formula, it is still not right. There seems to be one $+34.5 \%$ factor missing. What is it?

$$
+25 \%=(-2.5 \%)+(-17 \%)+(+10 \%)+(+34.5 \% ?)
$$

+25\%: yearly increase in Chinese students studying overseas equals

$-2.5 \%$ : declining rate of Gaokao takers (university-age population)

$-17 \%$ : increasing rate of higher education provision in China

$+10 \%$ : yearly rate of economic growth in China

$+34.5 \%$ : the missing positive push factor

\section{Chinese Educational Culture}

Demographics and economics are necessarily very important variables in making predictions about future Chinese student mobility. But these are only synchronic factors based on what we can observe today. Many people from the West use the word "inscrutable" to describe China and the Chinese people, a major reason being that they are unable to connect China today with China's long history, unable to go beyond their fixation on the short Communist era and see the historical continuity in Chinese ways of thinking and ways of life for 5,000 years. To understand what is going on in China today, a diachronic analysis of what has happened in its extensive history is absolutely crucial.

Without factoring in the long-standing and unique Chinese educational culture, any prediction of Chinese students' mobility will be incomplete. In this position paper, I 
would argue that the big, mysterious push factor in the above equation, $+34.5 \%$ being my attempt at a broad numerical estimate, is none other than traditional Chinese educational culture. However, culture is a very dangerous topic for discussion. Only hard-core cultural essentialists can claim to be able to pin down a culture in an objective fashion. That said, only making neutral and generic claims about cultural differences, such as "every culture is complex and every individual in each culture is different," is of little help for cross-cultural communication either.

In the following, I will analyze three major aspects of Chinese culture that pertain to Chinese parents' and students' educational behaviours and China's educational landscape today: (i) the education-first culture; (ii) the saving culture; and (iii) the extended-family culture. The analysis is based on personal reflection upon my educational experiences in China; this reflection has also been sharpened by my cross-cultural experience of living and working in Canada. I was born and raised in Mainland China and was educated there from kindergarten to PhD. I also taught in two Chinese universities. But my most active attempt to make meaning out of my experience in China started when I moved to Canada about four years ago, employed first as a postdoc in education and then as an international official in a major Canadian university, working on China relations. I began to read the work of other Chinese scholars who also had traveled across the Pacific Ocean to North America and subsequently reflected back on Chinese culture. Particularly significant were: Fung (1948) who was the first Chinese scholar to introduce Chinese philosophy systematically to Western readers; Lin (1935), who wrote about Chinese culture when living in New York City in the 1930 s and whose book became a popular reference in North America for understanding China; and Fei (1992), who was trained in Western anthropology and wrote about Chinese sociology in the 1940s, at the height of the Japanese invasion of China.

The pre-Communist literature on Chinese culture and society shows striking similarities between what was observed then and what can be observed in China today. Something deep and fundamental about Chinese culture has not changed, despite the influx of Western influences in the modern era, socialism being one of them. Such consistency is also observable in modern Confucian scholars' works (see, e.g., Tu, 2000). Although subject to gradual ongoing change, some of the Chinese cultural schemas, the ways of thinking ascribed to by the majority of the population, are, on the whole stable (Strauss \& Quinn, 1997). The deep and fundamental part of Chinese culture that has to a large extent assimilated the invading alien cultures in history, the Mongolian and the Manchu cultures in particular, is gradually assimilating Marxist ideology, as shown in the prevailing concept of socialism with Chinese characteristics.

Given my linguistic background, my attention was also drawn to the Chinese language and everyday idioms/sayings that demonstrate the Chinese attitude toward children's education. According to the Sapir-Whorf hypothesis, language encrypts human experience and human thoughts, but at the same it influences or even shapes the thinking and behaviour of its speakers (e.g., Cook \& Bassette, 2010). The Chinese language that has recorded what the Chinese people experienced over their long history is also a window into the psychology of the Chinese people today. The semantically rich Chinese language provides a fertile ground for the hermeneutic meaning-making process of imagining what it was like to live during that extensive history. 
When discussing qualitative issues such as culture, it is hard for subjectivity to be avoided, but in this paper I try to add rigor to my interpretive inquiry by triangulating my embodied transcultural experience with the existing literature and the everyday Chinese language that encodes the Chinese attitude toward education. This approach to the understanding of the Chinese educational culture aligns with van Manen's (1990) phenomenological method, in which the author seeks the meaning of life through writing and rewriting about the lived experiences of self and others. It also gains methodological insight from Clandinin and Connelly's (2000) narrative inquiry, which stresses the importance of autobiographical narrative in the understanding of educational phenomena. The paper aims to be a good starting point for discussions on the issue of Chinese educational culture in Canada, as more and more educators have to deal with Chinese students one way or another in this part of the world.

\section{The Education-First Culture}

The Chinese word “教to teach" literally means "to make filial." Filial piety was one of the important aspects of Confucius's teachings. Confucianism used to be one of the "hundred different schools of thought blossoming" around the time Confucius lived (551-479 BC). However, the rulers of China seem to have found Confucianism to be the ideological tool most conducive to consolidating their rules. According to a disciple of Confucius, You $\mathrm{Zi}$, few filial and fraternal people wish to offend their superiors, and none wish to rebel (Gu, 2006).

During the Han Dynasty (206 BC to 220 AD), all other schools of thoughts were banned, leaving only Confucianism to be pursued. Since then, Confucianism has become the core curriculum of Chinese education $(\mathrm{Gu}, 2006)$ and has almost acquired the status of a state religion, although most scholars in China do not see Confucianism as a religion. According to Fung (1948), Chinese people have been so interested in philosophy that there has been no space in China for religion. In a similar fashion, Buddhism is practiced in China more as a philosophy of life than as a religion of gods.

Traditionally in Confucian China, education was used to serve the goal of teaching moral ethics to people. It is the Chinese tradition of education to put moral education above the teaching of skills in trades, the humanities above the natural sciences $(\mathrm{Gu}, 2006)$. Chinese philosophy, as Fung (1948) argued, regardless of its different schools of thought, is directly or indirectly concerned with government and ethics. What occupied the minds and hearts of Chinese thinkers was society, not the universe; the daily functioning of human relations, not hell and heaven; man's present life, not his life in a world to come. Once, when Confucius was asked by a disciple about the meaning of death, he replied, "Not yet understanding life, how can you understand death?” (Analects, XI, 11; cited in Fung, 1948).

"Those who labour with their brains should govern those who labour with their brawn." This household Confucian proverb in China serves to show that the goal of education has been to produce men of virtue who could serve in government positions. Throughout Chinese history prior to the Opium War in 1839 (the first of a series of wars led by Western powers to invade China in modern Chinese history), education in China was overwhelmingly concerned with how one should conduct himself in society and how to become a statesman (Gu, 2006). To Chinese parents, education has been a pathway to officialdom, not to careers as tradesmen or engineers. 
This explains why Chinese parents today still insist on their children going to universities instead of vocational schools or colleges, despite some university graduates having difficulty finding employment, and the high demand for skilled tradespeople in China. In Canada, high enrolments in humanities and social science seem to be blamed for the so-called skill gap, the dearth in engineers and other skilled workers; in China, working in government as a civil servant has been the most sought-after career path for many. To many Chinese parents, white-collar jobs are the only acceptable occupations (Biao \& Shen, 2009). To address the shortage of skilled workers in China, the government recently announced its plan to convert some 600 universities into vocational colleges (Roberts, 2014). However, we will need to wait and see how long it will take the government's action to change Chinese parents' attitude toward their children's educational choices.

One historical development that strengthened the position of Confucianism in Chinese society was the imperial civil service examination system, known in China as "Ke Ju." This system existed for 1,300 years, from 605 (when it was established in the Sui Dynasty) to 1905 (when it was abolished in the Qing Dynasty). Through this system, all male adults in China, including those from humble social and economic origins, could change their fates by working hard on their learning and outperforming others in the exam (Lin, 1935).

Many Chinese scholars have criticized the system for the rigidity of its content and format, which in turn restricted people's thinking and scope of learning. However, the system also left important legacies. First, it weakened the hereditary power of the nobility by helping the descendants of nobility rid themselves of such habits as laziness, degeneracy, and corruption (Gu, 2006). For this reason, some Chinese scholars, Lin (1935) for example, have claimed that China's has been a classless society, with each member on an equal footing in terms of upward social mobility. Second, it has resulted in the formation of the education-first culture in China, reflected in such household sayings as: "Everything else is inferior, education is the only lofty pursuit," and "In books you will find beauties with complexions like jade, and houses made of gold."

Numerous stories circulated in China about young people of humble origin "borrowing light to read from a rich neighbour by drilling a hole in the wall," or borrowing money for the trip to the exam sites and "returning home in silk robes," riding big horses as red as dates. These stories served to motivate young people to stay awake to read, "with their hair suspended from a beam and using an awl to prick into the bone." In a way, I have strong connections with stories like these. Born and raised in one of China's poorest rural areas, I was inspired by those success stories, and I myself have become a success story to many children in my village, as I have made my way to university and away from the farm through my hard work.

The education-first culture can go a long way to explaining Chinese parents' commitment to their children's education. Despite the fact that the returns on investment in education in China are very low-about $3-5 \%$, lower than the $10.1 \%$ world average and the 9.6\% Asian average, as well as the 11.2-11.7\% range for low- and middle-income countries (Li, 2003)-individuals and families in China are still willing to invest in higher education as a means to secure both an expected higher income in the future and a more prominent social status, if they can afford to do so.

The education-first culture has been driving the fast growth of the domestic higher education sector in China over the past two decades. According to Marginson (2011), the 
fast expansion of the Chinese higher education sector since the 1990s has been driven not so much by increasing public or private investment, but rather by increasing household funding in the form of higher tuitions through the introduction of user-pay reform. The rise in tuition has not reduced the social demand for higher education. On the contrary, rapid tuition growth and massive university enrolment expansion have taken place side by side. The growing funding of tuition by households has also freed the government to invest selectively in a small group of elite universities through a differentiated funding model so as to compete with the world's major-league universities. This development may be unique to China, given that Chinese parents' "desires for (children's) education [are] stronger at the level of the whole population than elsewhere in the world" (Marginson, 2011, p. 595). One study in the USA showed that the price flexibility of demand for higher education in the USA was -0.62 (Leslie \& Brinkman, 1988, cited in Dong \& Wan, 2012), meaning that for every $10 \%$ increase in tuition fees, student enrolment dropped by $6.2 \%$.

The education-first culture has driven not only the rapid expansion of the domestic higher education sector but also the increasing number of Chinese students studying overseas. Domestic higher education and overseas higher education do not seem to be in fierce competition yet, as the demand for higher education, no matter where, is so high. Some scholars have seen international education as part of the phenomenon of "overeducation," which means that the educational returns are lower than the investments, and the skills acquired exceed the needs of the employer (Freeman, 1976; Tsang \& Levin, 1985; both cited in Biao \& Shen, 2009). But Chinese parents do not seem to care whether their educational investment yields as much return.

Chinese students who have finished their studies overseas and return to China for employment are often called "hai gui" (overseas returnees). The phrase sounds exactly the same as "sea turtle." They once had some semantic connection as well. Both suggested long voyages across the ocean; both were precious-the sea turtles are admired in Chinese culture for their longevity, and the overseas returnees were once precious and highly sought after by employers in China. However, in the past decade or so, the value of overseas returnees has depreciated by a large margin due to oversupply and improved domestic higher education. Many of them returned to China after completing their overseas studies but failed to land desirable, high-paying jobs, becoming what are sarcastically called "seaweed" (hai dai) or "work-waiting returnees."

The risk of their children returning as "seaweed" does not seem to dampen Chinese parents' enthusiasm for sending their children overseas. Returning to China as a "sea turtle" seems to be the lowest expectation of most Chinese parents for their children. The first option is always for them to study business at "world-class" universities, immigrate upon graduation, work in one of the world's top 500 companies, and live in big, North American, suburban homes. I know that a very good polytechnic institute in Canada has been trying to promote their diploma programs to students in China, but with little success. Chinese parents want their children to get at least a baccalaureate degree, if not a master's or a PhD, preferably in one of the world's top 100 universities. I also have heard about a Chinese girl who was sent by her parents to study business in Canada. While in Canada, she developed an interest in baking and decided to study that instead, which strained her relationship with her parents. 


\section{The Saving Culture}

The Chinese word for home is “家(Jia)," an ideograph showing a pig under a roof. This may confuse Western learners of Chinese. How can it mean "home"? A pigsty would make more sense. To understand this word requires imagining the lives of Chinese people across their long history. For thousands of years, China was predominantly a rural society. When the Chinese Communist Party began to lead China in 1949, only about 10\% of the Chinese population lived in cities (Shan, 2011). Rapid urbanization has only taken place in China over the last 30 years, as surplus rural labourers were brought into the cities to manufacture cheap "Made in China" products for the Western market. Currently, half of Chinese people still live in rural areas.

For a long time, Chinese farmers had very primitive and self-sufficient lives. Apart from the crops they grew, a pig was essential to the livelihood of a household, as it basically supplied all the meat needed throughout the year. This is the life my family has been living on a farm in northeastern China for as long as I can remember. Apart from feeding us, my mother's main duty has been feeding a couple of pigs from the beginning to the end of each year. We sold one for cash and killed the other one for the Spring Festival. In summer 2011, when I last visited my father's farm before I moved to Canada, I realized that this lifestyle had begun to change, as small-scale individual farms were starting to give way to larger-scale chicken farms and pig farms.

Just as English speakers from North America may find it hard to understand the Chinese character for "home," Chinese learners of English find it hard to understand the English word "tornado." What kind of wind is a tornado? Large areas of flat prairies in North America become good conditions for tornados to form, while in China there are too many mountains and hills for the tornados to develop. For the same reason, the percentage of arable agricultural land is lower in China. However, this has not stopped the Chinese people from producing many children. As I mentioned above, "filial piety" is the most important value of Confucianism, the ultimate goal of education. "The most serious of all violations of filial piety is failing to produce a male heir," according to a household Chinese Confucian saying. All humans may take pride in passing on the family name, but the Chinese took it to the extreme. This resulted in the concentration of a quarter of the world's population on $8 \%$ of the world's arable agricultural land.

Chinese people have always been hungry. "Have you eaten?" was, for a long time in Chinese history, the standard way people greeted each other, the equivalent of "How do you do?" or "How are you?" in English. Between 108 BC and 1911 AD, for example, there were over 1,800 famines in China, almost one a year in one location or another, resulting in the starvation and death of millions (Mallory, 1926). This seemingly eternal Chinese tragedy has forced people to try to eat anything that looked edible. Western people have the impression that the Chinese would eat anything that flies in the sky except for planes, and anything that runs on the land except for vehicles. Not only do they eat everything, but they eat every part of everything. When they eat the pigs, they eat the head, the face, the tongue, the brain, the liver, the heart, the kidneys, the intestines, the tail, and the feet. When they eat fish, they eat the fish head, the fish eyes, the fish brain and the fish tail. They eat different kinds of fish too, big or small, long or short, with or without prickly bones. When Westerners see a new organism, they might ask: "How can we classify this?" When the Chinese see the same organism, they might ask: "How can this be cooked?” (Lin, 1937). 
In modern Chinese history, the 1839 Opium War started a century of Chinese humiliation, during which the Chinese suffered the Second Opium War (1856-1860), the SinoJapanese War (1895-1898), the Eight Western Country Invasion (1900), the Republican War (1911-1912), and the Chinese Civil War (1927-1937 and 1946-1949) with the eightyear Anti-Japanese Invasion War in between (1937-1945). The most recent Chinese tragedy was a famine during the Cultural Revolution (1966-1976); when the Chinese people finished eating the corns on cobs, they ate the cobs as well. After they finished the cobs, they turned to the leaves, barks, and roots of trees. After those were finished, they turned to frogs in the river. These are the stories I heard from elders back in my home village who experienced the Cultural Revolution. But Westerners do not need to pity the Chinese, a people who believe in the value of "eating bitterness." One positive result of such bitter experiences has been the richness and wide variety of Chinese cuisine. Given time and some ingenuity, the Chinese turned everything they ate into delicacies. When they were no longer poor, they started to enjoy the diverse culinary traditions of different parts of the country.

However, through history, ruling such a large, hungry population has proven to be a very difficult task for any government. The Chinese government has never troubled to colonize other countries or regions, even though they had the technical capacity, as they were kept too busy domestically (Jacques, 2012). And the Chinese people, throughout their long history, have seen dynasties come and dynasties go, none of which was able to fundamentally change their fate. Over time, the Chinese people have learned to become cynical about governments and social change. The cycles of ups and downs have also made them terribly patient. In times of war and social unrest, they have continued to sip their tea and play their chess, waiting for the fortune to change (Lin, 1935).

"The sky is high, and the emperor is far away." This old Chinese saying well captures the kind of life Chinese people have been living. They do not believe in God (the sky). It is too high above. Without an almighty god in their minds and hearts, their lives have been balanced between Confucianism and Taoism (Lin, 1935), two very different philosophies but somehow working together for the benefit of Chinese people. Confucianism encourages people to actively engage in social affairs, pursuing a government career if possible. Taoism encourages people to withdraw from the messiness of society and pursue inner harmony by living a simple life close to nature. As Lin (1935) said, Chinese people are Confucianists when they are successful and Taoists when they experience failure.

The Chinese people did not believe in the emperor either. He was too far away. They have had very low expectations regarding social welfare from the government. Storm "Sandy" victims (2012) in the USA angrily demanded, on television, that the government "help and help right now." The Sichuan earthquake (2008) survivors simply shed tears in front of the media, feeling sad for themselves. The best government, in the view of Chinese people over their long history, has been one that left them alone. They "feared government tax collectors more than tigers," a phrase based on a Confucian story in which a family chose to live in a tiger-roaming area to avoid government taxation. Apart from the slight psychological warmth they may derive from worshiping their deceased families, the Chinese people have learned to be self-reliant.

This spirit of self-reliance has resulted in the Chinese people having a saving culture. "Thatch your roof before it rains." China's household savings rate is higher than in any other country; Chinese people typically save about a third of their total incomes (Liu, 
2014). Hence, while the Canadian Minister of Finance is urging Canadians to save, the Chinese government is trying to figure out how to make people spend more. However, no matter how hard the government tries to stimulate domestic consumption, the Chinese continue to save on a big scale. As mentioned above, saving has been a necessity for survival during the course of Chinese history. Precautionary saving for an unpredictable future is still a major economic reason behind Chinese saving behaviour, given the country's less than satisfactory social and health care systems. Compared with Canada, whose social welfare system is more socialist than China's, Chinese people have to save up in the event of major diseases, and for their children's higher education. But increasingly, saving is no longer an absolute necessity but instead continues more as a habit. Just as the lack of cow's milk in Chinese history has resulted in Chinese people's lactose intolerance, their saving behaviour is "in their blood."

Saving is the habit not just of individuals and households but of corporations and the country as a whole. It is a valuable habit, especially in the context of the financial crisis that resulted from lavish spending and virtually no saving in the Western world. Many Canadians may wonder how Chinese families can afford to send their children to go to university in Canada, where each international student needs to spend at least CAD 30,000 a year. That is 23 times the per capita annual disposable income of urban residents in China (in 2007) and 70 times that of rural residents' (Biao \& Shen, 2009). When Canadian parents are complaining about the high cost of higher education, how can Chinese parents afford to pay international tuition fees, which are typically three times as high as domestic fees? In addition, given the current exchange rate of about five RMB to the Canadian dollar, the answer lies partially in the Chinese saving culture.

Chinese parents are highly committed to supporting their children's schooling, as was analyzed above. Most middle- or lower-middle-class families, a soon as children are born, economize on food and clothing on a daily basis to save for their children's education. Chinese parents, especially those on salaries, might have saved for ages for their only child's education expenses. They have a frugal lifestyle, spending only on the mere essentials. If their savings are not enough, they are willing to "break their cooking wok to sell as scrap iron" (another Chinese saying) to pay for their children's tuitions. Parents in North America let their children take out loans to pay for college fees. This would be a disgrace for Chinese families.

\section{The Extended-Family Culture}

The essence of the Confucian value system is "benevolence" or simply "love." The Chinese character for "benevolence" is “仁ren," with the left radical representing “人” (people) and the right radical representing "二” (two). As the formation of the Chinese character shows, "benevolence," or Confucianism as a whole, is about the moral principles that regulate the person-to-person relationship. "There should be affection between father and son, righteousness between king and subject, difference between husband and wife, order between older and younger brother, loyalty between friends." It was Confucius's idea that, if everyone in society is assigned a specific role and people in different roles interact according to certain rituals and protocols, the world will be at peace.

If we look more closely, we may realize that the five relationships mentioned abovefather-son, king-subject, husband-wife, older-younger brother, and friend-friend-are 
discussed together in no particular order, such as family first, non-family second. This shows that, to Confucius, the hierarchical relationship between father and son can be applied to the other sets of human relations: "Fathers as fathers and sons as sons." The value of filial piety dictates that sons are supposed to submit and listen to their fathers and other elders. The same rule applies to the husband-wife and older-younger brother relationships, with the latter submitting to the former. The rule also applies to the kingsubject and friend-friend relationships. The king's man should listen to the king, just as a son listens to his dad. In a friendship, younger buddies should listen to older buddies, just as younger brothers listen to older brothers.

In the eyes of many Westerners, this is a backward, authoritarian system that should be changed to their democratic and humanitarian ways. However, such a belief tends to fail to see the complexity of a system that may not be democratic in Western terms, but is highly humanistic. The emperor ruled with the "Mandate of Heaven," but to deserve the Mandate awarded to him, the emperor needed to rule with the utmost level of ethics and humanism. Any natural disaster, which was a yearly occurrence (as mentioned above), could be interpreted as the withdrawal of the "Mandate of Heaven" and thus conferred the right for a social uprising to remove the emperor from his throne (see, e.g., Jacques, 2012). The father has the absolute authority in the family, but he also has the absolute responsibility to provide for the family, and this responsibility lasts beyond his children's 18th birthday. Chinese parents are supposed to save and pay for their children's university education, as mentioned above. Chinese parents are also supposed to contribute to the down payment and furnishing of their children's first house; once the house is in place, they are supposed to pay for their children's weddings as well.

Chinese people retire early, men at 55 to 60 years old, women at 50 to 55. Many Westerners may see the deprivation of the right to work after a certain age as discriminatory. However, many Chinese seniors do not seem to mind this. Instead of having nothing to do, they take up a new job right after retirement, helping to look after their grandchildren while both parents work full-time. Canadian grandparents may come and visit a newborn for a week or two; when my first son was born in 2007, my in-laws moved in and basically took over the baby! It is the responsibility of the parents and the grandparents to raise and educate the only child in the family.

According to Fei (1992), Chinese society is organized according to different principles from those prevailing in the West. Western society can be compared to a haystack of straws collected together. People organize into social groups through voluntary, unambiguous membership. It is voluntary because each individual has the freedom to join or leave. It is unambiguous because members of each group have clearly delineated rights and responsibilities. It is a haystack with each straw as a free individual joining the group as an equal member.

The haystack-style of social organization is based on the Western individualistic tradition, according to Fei (1992). Each individual is a soul-bearing self, linked to the creator, God. The individual's identity is defined not by the people around him in a social organization but by his connection with God. In Canada, only about $5 \%$ of the population goes to church regularly, but in the 2011 Canadian census, $67 \%$ of Canadians claim adherence to Christianity (Statistics Canada, 2014). When the majority of the population declares themselves the followers of one God, the government tends to have a very easy time rul- 
ing. Constitutions in Western societies typically connect with Christianity by declaring that they protect the rights of all individuals as being created equal. It is by connecting with God that the government gains its legitimacy to rule, although the church and the government have long been severed. God often appears in their currencies and national anthems. In Canada, people do not seem to trust the government very much and are often cynical about government policies. But consciously or subconsciously, Canadians tend to subscribe to a set of higher moral principles informed by Christianity. God is omnipresent. If one is to be accountable to God, he needs to be on his best behaviour at all times and in all places. My observation in Canada seems to align with Fei's (1992) analysis, although there are always exceptions.

Different from a haystack, the Chinese people's social organization can be compared to the ripples flowing out from the splash of a rock thrown into water (Fei, 1992). The ripples feature overlapping networks of people linked together through differentially categorized social relationships. The centre of each network is a nuclear family. The family expands outward to bring in other people into a bigger pseudo-family network. The network connects the individual with other individuals through different relational ties, called Guanxi. Each Guanxi is strictly personal, and its maintenance is based on principles of reciprocity and personal obligations. In this way, there are no formal channels for social operations. There are only personal ones. If one wants to get things done, the first impulse is always to seek Guanxi, or personal relationships. My experience seems to show that the formal public channel is more open and more available to people in Canada. I, as a foreigner, can get the same information from any government office as any Canadian citizen.

What is important to point out here is that the moral standards in a Guanxi network are situational, not universal. To be more specific, in the ripple network in China, one's obligations to family and kinship ties closer to the centre of the network override the obligation to more distant Guanxi ties. What is practiced in the centre of the family network is a very ideal form of communism, whereby resources are managed and allocated not equally but collectively according to needs. Based on the education-first culture, resources are overwhelmingly channelled toward the education of what is often the only child in the family, as a priority.

The tight and extended family network has resulted in the historic resilience of Chinese culture at large. China was ruled by the Mongolians for a century (1271-1368), a period called the Yuan Dynasty. China was ruled by the Manchurians for nearly three centuries (1644-1911), a period called the Qing Dynasty. In the eyes of Chinese historians, these two periods were integral parts of the continuous flow of Chinese history. They are not regarded as China falling under the rule of foreign invaders. China boasts 56 ethnic groups, with Han people comprising over $90 \%$ of the population. The Mongolians and the Manchurians are considered two minority groups in China. Indeed, in terms of culture and language, the Chinese language and Han culture stayed intact during the rule of the non-Han "aliens" that the Great Wall was supposed to keep at bay. Instead of being assimilated by the incoming ruling cultures, the Han culture assimilated the alien cultures. According to Lin (1935), the tight family structure was the very reason why Chinese culture has maintained continuity despite the invasions of external groups and cultures.

How does Chinese family culture relate to the mobility of Chinese students overseas? Wouldn't the extended family affection serve to keep Chinese students (in most cases the 
only children of their families) at home, close to their parents and grandparents, instead of pushing them overseas? To understand this seeming contradiction, we might need to resort to a bit of the yin-yang dialectic, the tension and yet the union between two opposite tendencies. One Chinese saying that is often quoted to defend the practice of physically punishing children is, "Hitting is caring, scolding is loving," similar to the Western concept of "tough love." It is not an easy decision for Chinese parents to send their children overseas for education, as they are aware of the difficulties their children will have to go through to succeed: language barriers, culture shock, independent living, homesickness, to name just a few. But they are convinced that children need to "eat bitterness" (a Chinese phrase mentioned above) in order to achieve bigger success.

High achievement in learning is seen as an ethical act of filial piety, as an educated and successful offspring brings honour to the family and protects the prosperity and continuation of the line (Marginson, 2011). In the extended family culture, one's value is measured not on an individual basis but by how he or she contributes to the prosperity of the family network. Whether a student goes overseas to study is often not an individual decision made by the student, but a collective decision made by the whole family. One important reason for the mobility of Chinese students overseas is the "whole family" approach to reproducing social advantage within families (Brooks \& Waters, 2011). International tuition fees might generate a big financial burden, but the burden is mitigated when the high-saving parents, two sets of high-saving grandparents, and numerous high-saving aunts and uncles decide to pitch in.

My discussion in this paper so far has focused solely on adult Chinese students attending overseas institutions of higher learning. However, a major trend in Chinese students' overseas education is that students are studying overseas at an increasingly younger age (EOL, 2014). Homestay is one arrangement, while the "astronaut" family is the other, wherein one parent, typically the mother, relocates to manage the children's schooling overseas, and the other parent, typically the father, stays in China to look after his career or business (Huang \& Yeoh, 2005; Waters, 2002). In the astronaut arrangement, parents have to make tremendous sacrifices, such as separation, loneliness, and other hardships. However, Chinese parents still deem the plan worthwhile, as it ensures better education opportunities and better futures for their children. Most, if not all, Chinese people are familiar with the story of Mencius's mother moving house three times to ensure the most conducive educational environment for her son. Chinese parents are willing to give up their convenience and personal comfort to find or create such a good educational environment for their children. It is the share of the "bitterness" parents have to "eat."

\section{Discussion}

To say that only the Chinese emphasize their children's education is almost offensive to other cultures, as parents of all cultures would like to give their children the best, including the best education. However, Chinese parents might be unique in the extent of the sacrifices they are willing to make so that their children can get the best education possible, irrespective of the return. The Chinese education-first culture is partly rooted in a highly competitive social structure, the result of a large population and scarce educational resources. Compared with Canada, the income gap between white-collar workers and blue-collar workers in China has been historically large. Canadian parents can afford 
to give their children more freedom in educational options, as tradespeople often make more money than office workers. Chinese parents tend to push their children as hard as they can, so that they can exhaust their intellectual potential in their schooling. Chinese parents often regard overseas education as a means of providing extra advantages in the fierce competition for scarce resources and opportunities (Biao \& Shen, 2009).

The Chinese education-first culture makes Chinese parents seek the highest educational options for their children, and the saving culture and extended-family culture are enabling factors that help prioritize the allocation of resources to their children's education. For K-12, Chinese parents want to send their children to the best public schools. This has driven up the housing prices in some school districts. If parents are not able to live in a good school district, they are willing to pay high "school selection fees" so that their children can go to a better school away from their home district. When it comes to university, they want their children to go to a top-tier university, ideally in Beijing or Shanghai. If the family is sufficiently well off, they will consider sending their children overseas, preferably to the USA. Overseas higher education is generally perceived to be better than what is available in China. According to the 2014 Shanghai Ranking of the world's top 500 universities (http://www.shanghairanking.com/ARWU2014.html), 146 are from the USA, most of these leading the league table, while only 32 are from China, mostly at the bottom.

Aside from the USA, Chinese parents tend to consider the UK, Canada, Australia, and other English-speaking countries. Apart from university rankings, English language is another factor in their choice of overseas education destinations. The global village we live in seems to have necessitated the existence of a global language. Despite the fact that the rise of the English language was connected to British colonial history, people around the world seem to accept rather uncritically the status of English as an international lingua franca. English as an important part of the school curriculum since the later 19th century has enjoyed very high social status in China. The policy of opening up to the outside world, implemented in China since the late 1970s has made English proficiency a highly valuable skill for employment in an export-oriented economy. Chinese parents see the value of investing in English-medium higher education.

The three elements of Chinese educational culture that have served to drive Chinese students' international mobility are not new. They have been around for several dozen centuries and will remain, if not strengthen. The Chinese educational culture, given its consistent nature, will continue to drive Chinese students' outbound mobility in the foreseeable future. The Chinese government has been increasing its investment in the Chinese higher education sector, and Chinese universities are improving their performance in world university rankings. However, it might take a couple of decades, if not longer, before the top Chinese universities are on a par with their counterparts in the West. And in the foreseeable future, Chinese parents will continue to attach importance to English-medium education. Language status and economic power go hand in hand. We are still not sure whether English has already reached its peak as a world language, similar to Latin in the Middle Ages and French in the 18th century. The only possible alternative to English as a world language might be Chinese, given the current state of economic development in the world. But again, in the foreseeable future, English will remain the world language.

Will the Chinese government interfere with students' outbound mobility for fear of brain drain? The Chinese policy on self-financed overseas education has been very consis- 
tent since 1981, and it is a very liberal policy: "support study overseas, encourage returns, and guarantee freedom of movement" (Biao \& Shen, 2009). "When the leaves fall, they fall to their root." Convinced by this Chinese saying, the government seems to believe that whether or not Chinese students return, having them study overseas will benefit China in the long run. In addition, despite the large absolute number of Chinese students seeking overseas education, they comprise only a small percentage of the total Chinese students in higher education. According to UNESCO statistics in 2005, only 1.85\% of Chinese college students were studying overseas, compared with 3.03\% from South Korea, 6.16\% from Malaysia, and 22.8\% from Hong Kong (UNESCO, 2007, cited in Biao \& Shen, 2009). Given the huge demand for higher education in China, Chinese universities are still very selective in admitting students and do not need to compete with overseas universities.

On the supply side, the host countries of international students, given their financial interest, will continue to provide elite higher education opportunities to a world market (Findlay, 2010). Most host countries, including the USA, the UK, Canada, Australia, and New Zealand, have long treated higher education as an important export industry. Apart from revenues in the form of tuition fees and living expenses, these governments also use international education as a base to recruit quality labour forces to fill the gap left by aging populations and low birth rates. At the same time, as global education caters to affluent families in the countries sending international students, it serves to strengthen the power of social elites and perpetuate the unequivocal social structure in these societies. This is the unethical dimension of global education that Western countries need to face. Take Canada, for example: at about the same time as the government mandated its universities to double their international student recruits in 10 years, it cut its direct foreign aid to 14 developing countries, including China. While benefiting from the financial gain and brain gain in international education, Canada needs to think about how to engage in development projects to help achieve education equity in the societies from which we receive students.

\section{Conclusion}

Chinese behaviour patterns and deep cultural norms, shaped by historical experiences, are typically beyond scientific analysis, as such analysis often stays at the surface of the phenomena, using currently observable or obtainable data, but fails to reach the depth of the old Chinese soul. In addition to economic and demographic factors, traditional Chinese educational culture is another major push factor for Chinese students' international mobility. The education-first culture encourages parents to try to send their children to the best institutions possible, as far as they can afford. At the current stage of history, an English-medium Western education is perceived by most Chinese parents as superior to a domestic one. The saving culture makes Western tuition fees affordable to many middle-class Chinese families. And the extended-family culture makes one student's higher education a priority for the whole extended family. It is often a big family decision, with the commitment of resources from the whole family. These features of traditional Chinese culture, together with economic growth, will continue to drive the outbound mobility of Chinese students for a few decades to come. 


\section{Acknowledgements}

I would like to thank Ms. Britta Baron and Dr. Cen Huang for the opportunity to work in international education at the University of Alberta International, which has opened new windows for my academic pursuits.

\section{References}

Altbach, P. G. (1998). Comparative higher education: Knowledge, the university, and development. Hong Kong, PRC: Comparative Education Research Centre, The University of Hong Kong.

Bai, L. (2006). Graduate unemployment: Dilemmas and challenges in China's move to mass higher education. The China Quarterly, 185, 128-144. doi:10.1017/ So305741006000087

Biao, X., \& Shen, W. (2009). International student migration and social stratification in China, Journal of Educational Development, 29(5), 513-522. doi:10.1016/j. ijedudev.2009.04.006

Böhm, A., Follari, M., Hewett, A., Jones, S., Kemp, N., Meares, D., Pearce, D, \& Van Cauter, K. (2004). Vision 2020. Forecasting international student mobility: A UK perspective. Retrieved from https://www.britishcouncil.org/sites/default/files/ vision-2020.pdf

Brandenburg, U., \& Zhu, J. (2007). Higher education in China in the light of massification and demographic change: Lessons to be learned for Germany. Retrieved from http://ids.hof.uni-halle.de/documents/t1599.pdf

Brooks, R., \& Waters, J. (2011). Student mobilities, migration and the internationalization of higher education. London, UK: Palgrave Macmillan.

Canadian Bureau of International Education (CBIE). (2014, November 23). Canada's performance and potential in international education 2015. Retrieved from http://www. cbie.ca/about-ie/facts-and-figures/

Clandinin, J., \& Connelly, M. (2000). Narrative inquiry: Experience and story in qualitative research. San Francisco, CA: Jossey-Bass.

Cook, V., \& Bassetti, B. (2010). Language and bilingual cognition. Hove, UK: Psychology Press.

Dong, H., \& Wan, X. (2012). Higher education tuition and fees in China: Implications and impacts on affordability and educational equity. Current Issues in Education, 15(1), 1-9.

Education Online (EOL). (2014, November 19). 2014年出国留学趋势报告 [A 2014 report on the trends of Chinese students' overseas education]. Retrieved from http:// www.eol.cn/html/lx/2014baogao/content.html\#01

Fei, X. (1992). From the soil: The foundations of Chinese society: A translation of Fei Xiaotong's Xiangtu Zhongguo. Berkeley, CA: University of California Press.

Findlay, A. M. (2010). An assessment of supply and demand-side theorizations of international student mobility. International Migration, 49(2), 162-190. 
Fung, Y. L. (1948). A short history of Chinese philosophy. New York, NY: The Free Press.

$\mathrm{Gu}, \mathrm{M}$. (2006). An analysis of the impact of traditional Chinese culture on Chinese education. Frontier of Education in China, 2, 169-190. doi: 10.1007/s 11516-006-0001-8

Huang, S., \& Yeoh. B. (2005). Transnational families and their children's education: China's "study mothers" in Singapore. Global Networks, 5(4), 379-400

Jacques, M. (2012). When China rules the world: The end of the Western world and the birth of a new global order (2nd ed.). New York, NY: Penguin.

Li, H. (2003). Economic transition and returns to education in China. Economics of Education Review, 22, 317-328.

Lin, Y. (1935). My country and my people. New York, NY: Reynal \& Hitchcock.

Lin, Y. (1937). The importance of living. New York, NY: William Morrow and Company.

Liu, Z. (2014, February 3). Job uncertainty and Chinese household savings. FRBSF Economic Letter. Retrieved from http://www.frbsf.org/economic-research/publications/ economic-letter/2014/february/job-uncertainty-china-household-savings-state-ownedenterprises-iron-rice-bowl/

Mallory, W. H. (1926). China: Land offamine. New York, NY: American Geographical Society.

Marginson, S. (2011). Higher education in East Asia and Singapore: Rise of the Confucian Model. Higher Education, 61, 587-611. doi:10.1007/s10734-010-9384-9

Mazzarol, T., and Soutar, G. N. (2001). The global market for higher education: Sustainable competitive strategies for the new millennium. Cheltenham, UK: Edward Elgar.

People.cn. (2014, February 24). 2013年共41万人出国留学 72.83\%选择归国发展 [Over 410,000 study overseas; $71.83 \%$ choose to return upon graduation]. Retrieved from http://edu.people.com.cn/n/2014/o224/c1053-24444292.html

Roberts, D. (2014, June 24). China wants fewer college grads, more skilled workers: Sound familiar? Bloomberg Business. Retrieved from http://www.businessweek.com/ articles/2014-06-24/china-wants-more-vocational-students-fewer-universities

Roslyn Kunin \& Associates, Inc., (2012, May). Economic impact of international education in Canada: An update (final report). Retrieved from http://www.international. gc.ca/education/report-rapport/economic-impact-economique/index.aspx?view $=\mathrm{d}_{\text {_ }}$

Shan, J. (2011, April 29). Census: Population hits 1.37b. China Daily. Retrieved from http://europe.chinadaily.com.cn/china/2011-04/29/content_12418282.htm

Sina Education. (2015, June 18). 1977-2014历年全国高考人数和录取统计 [Numbers of Gaokao takers and numbers admitted into universities 1977-2014]. Retrieved from http://edu.sina.com.cn/gaokao/2015-06-18/1435473862.shtml

Statistics Canada. (2012, September 12). University tuition fees. Retrieved from http://www.statcan.gc.ca/daily-quotidien/120912/dq120912a-eng.htm

Statistics Canada. (2014, January 13). 2011 census. Retrieved from http://www12. statcan.gc.ca/census-recensement/index-eng.cfm 
Strauss, C., \& Quinn, N. (1997). A cognitive theory of cultural meaning. Cambridge, UK: Cambridge University Press.

Tu, W. (2000). Implications of the rise of "Confucian" East Asia. Daedalus, 129(1), 195-218.

van Manen, M. (1990). Researching lived experience: Human science for an action sensitive pedagogy. New York, NY: SUNY Press.

Wang, Y. (2015, October 6). 2014中国出国留学人数再增共约46万人 [Chinese students studying overseas increased to about 0.46 million in 2014]. 政经频道 [Political and Economic Channel]. Retrieved from http://china.caixin.com/2015-03-06/100788923. html

Waters, J. L. (2002). Flexible families? "Astronaut" households and the experiences of lone mothers in Vancouver, British Colombia. Social \& Cultural Geography, 3(2), 117134 .

Yangtze Evening Post. (2012, October 8). China leads world in students overseas. Retrieved from http://www.globaltimes.cn/content/736957.shtml

Zha, Q. (2011). The study-abroad fever among Chinese students. International Higher Education, 69, 15-17. Retrieved from https://ejournals.bc.edu/ojs/index.php/ ihe/article/viewFile/8635/7767

\section{Contact Information}

Wei Liu

University of Alberta

weidavid@ualberta.ca

Wei Liu works at the University of Alberta, managing the Global Academic Leadership Development program, a professional development initiative for university administrators from other countries. He has a PhD from Beijing Normal University in Foreign Language Education and Teacher Education, and he was the 2011-2012 Horowitz Postdoctoral Research Fellow at the Centre for Research for Teacher Education and Development, University of Alberta. His current research interests include foreign language education and international education. 